\title{
Increasing the power output of hydrogen internal combustion engines by means of supercharging and exhaust gas recirculation
}

\author{
S. Verhelst*, P. Maesschalck, N. Rombaut and R. Sierens \\ Department of Flow, Heat and Combustion Mechanics \\ Ghent University \\ Sint-Pietersnieuwstraat 41, B-9000 Gent, Belgium \\ *corresponding author: T +32 9264 3306; F +32 9264 3590; E-mail Sebastian.Verhelst@,UGent.be
}

\begin{abstract}
Spark ignition engines can be relatively easily converted to hydrogen using port fuel injection (PFI). However, because of the lower volumetric energy density of a hydrogen-air mixture and the occurrence of abnormal combustion phenomena such as backfire, hydrogen-fueled PFI engines suffer from a power deficit in comparison with gasoline engines. This paper reports measurements on a single cylinder hydrogen engine equipped with a supercharger and an exhaust gas recirculation (EGR) system. Using EGR combined with supercharging and a three-way catalyst (TWC) is shown to significantly increase the power output while limiting tailpipe emissions of oxides of nitrogen $\left(\mathrm{NO}_{\mathrm{X}}\right)$.
\end{abstract}

Keywords: Hydrogen ICE; supercharging; EGR; efficiency; emissions

\section{Nomenclature}

Greek Symbols

$\lambda \quad$ air to fuel equivalence ratio

Abbreviations

bmep brake mean effective pressure

BTDC before top dead center

BTE brake thermal efficiency

EGR exhaust gas recirculation

ICE internal combustion engine

MBT minimum spark advance for best torque

$\mathrm{M}_{\mathrm{e}} \quad$ brake torque

$\mathrm{NO}_{\mathrm{X}}$ oxides of nitrogen $\left(\mathrm{NO}+\mathrm{NO}_{2}\right)$

PFI port fuel injection

$\mathrm{P}_{\mathrm{e}} \quad$ brake power

TDC top dead center

TWC three-way catalyst

WOT wide open throttle 


\section{Introduction}

Hydrogen is acknowledged to offer great potential as an energy carrier for transport applications. A number of technologies can use hydrogen as an energy carrier, with the internal combustion engine (ICE) being the most mature technology, and the fuel cell being the most promising one. This paper focuses on the hydrogen-fueled ICE, which has the advantage of being fuel-flexible, durable, and relatively cheap [1].

The easiest way to introduce hydrogen ICEs is by converting a gasoline engine to bi-fuel operation, by mounting a hydrogen fuel system and gas injectors. Starting from a gasoline engine implies port fuel injection (PFI) of the hydrogen. Therefore, this paper concentrates on hydrogen PFI engines, although dedicated hydrogen engines would benefit greatly from direct injection [1,2].

A PFI hydrogen engine operating stoichiometric at WOT, has a theoretical power deficit of about $15 \%$ compared to a gasoline engine, due to the lower volumetric energy density [3]. In practice, the power deficit can be even higher if the equivalence ratio has to be limited to avoid abnormal combustion. Variable valve timing has been used to enable hydrogen engines to run stoichiometric without backfire [4], through better scavenging of hot exhaust gases. Supercharging is a means to further increase the power output, to gasoline levels or higher.

Natkin et al. at Ford [5] report work on a supercharged 2.3 liter PFI engine. Using a standard (air to air) intercooler and a fixed equivalence ratio of $\lambda=2$ so that after treatment is not necessary, resulted in a torque deficit of $28 \%$ compared to the base (naturally aspirated) gasoline engine. Going richer (the exact equivalence ratio was not specified) and adding an extra air-conditioning to air intercooler was necessary to restore the torque level to that of the gasoline engine. What this did to the $\mathrm{NO}_{\mathrm{x}}$ emissions was not given in the paper. In the recently introduced Ford E-450 $\mathrm{H}_{2} \mathrm{ICE}$ vehicles, a 6.8 liter supercharged PFI engine is used at a lean equivalence ratio (not specified) eliminating the need for after treatment [6]. The engine has a maximum power output of $173 \mathrm{~kW}$ and maximum torque of $420 \mathrm{Nm}$ (corresponding with a bmep of 7.8 bar).

Berckmüller et al. at BMW [4] report work on a supercharged stoichiometric $\mathrm{H}_{2}$ engine, reaching peak power outputs of about one third above that of an atmospheric gasoline engine. Compared to the naturally aspirated case, they had to lower the compression ratio from 12 to $11: 1$ when charging to 0.85 barg to enable stoichiometric operation without the occurrence of pre-ignition. The cylinder head coolant flow and the valve timing were optimized to minimize surface ignition tendencies. The stoichiometric operation allows an efficient after treatment using a three way catalyst (TWC, for hydrogen perhaps better referred to as a 'two way catalyst', as its function is to reduce $\mathrm{NO}_{\mathrm{X}}$ emissions and oxidize unburned hydrogen emissions) so that tailpipe $\mathrm{NO}_{\mathrm{X}}$ is within acceptable limits.

White et al. [7] present a review of $\mathrm{H}_{2}$ ICEs in which they discuss work on boosted $\mathrm{H}_{2}$ ICEs, concluding that such engines are a compelling alternative to fuel cells when used in a series hybrid vehicle, at lean equivalence ratios so that very low emissions are reached without any after treatment. 
At Ghent University, two PFI hydrogen engines were supercharged in an effort to increase the power output. For one of the engines (Valmet 4.4 liter four cylinder) this was unsuccessful as the occurrence of backfire necessitated leaner mixtures, effectively resulting in the same power output as the atmospheric engine [8]. For the other engine (GM 7.4 liter V8), maximum torque output could be increased by $60 \%$ compared to the atmospheric case. The increase in power output was less substantial as leaner mixtures were necessary at the higher engine speeds to avoid backfire [9]. With both engines, supercharging was done at lean mixtures to limit $\mathrm{NO}_{\mathrm{X}}$ formation.

From the above, it is clear that there are a number of operating strategies for hydrogen engines $[1,10]$, which depend on the power demand, and are related to the limitation of $\mathrm{NO}_{\mathrm{X}}$ emissions. At low loads, the load can be controlled by the equivalence ratio (qualitative approach), as combustion temperatures then stay below the $\mathrm{NO}_{\mathrm{X}}$ formation temperature. The engine is then run under wide open throttle conditions, so that pumping losses are negligible which benefits the brake thermal efficiency [11]. For medium to high power demand, using this approach leads to high $\mathrm{NO}_{\mathrm{X}}$ emissions, once the equivalence ratio becomes richer than some threshold. For most engines this threshold is around $\lambda \sim 2$. The high $\mathrm{NO}_{\mathrm{X}}$ emissions for mixtures richer than this threshold are difficult to reduce with after treatment, as the mixture is still lean and thus the exhaust is oxygen-rich.

There are two options for $\mathrm{H}_{2} \mathrm{ICEs}$ to obtain power outputs similar to or exceeding the power output of an equivalent, naturally aspirated, gasoline engine, without excessive tailpipe $\mathrm{NO}_{\mathrm{X}}$ emissions. The first option is to stay lean of the 'threshold equivalence ratio', the air to fuel equivalence ratio below which $\mathrm{NO}_{\mathrm{X}}$ emissions rise exponentially, and make up for the power loss caused by the lean mixtures through supercharging. The second option is supercharging at stoichiometric mixtures, or in practice at slightly rich of stoichiometric so that a small amount of unburned hydrogen is present in the exhaust which is an effective reducing agent for $\mathrm{NO}_{\mathrm{X}}$, using a three way catalyst [12]. The current paper presents measurements on a single cylinder supercharged hydrogen engine using both options.

The second option, running at stoichiometric, is not always possible without occurrence of abnormal combustion phenomena. Using exhaust gas recirculation (EGR) is a means to allow reliable stoichiometric operation. Furthermore, varying the EGR rate can be used to control the power output (as opposed to throttling) which benefits the engine efficiency $[4,13]$, and $\mathrm{NO}_{\mathrm{X}}$ emissions decrease because of the thermal inertia of the EGR gases.

\section{Experimental set-up}

\subsection{Engine}

The single cylinder two valve engine used in this study is based on an Audi-NSU research engine. It has a swept volume of $400 \mathrm{cc}$. The compression ratio was set at 11:1 by machining a DI diesel piston. The engine is coupled to a DC motor and is operated between 1500 and $4500 \mathrm{rpm}$. Two Teleflex GSI gas injectors are used for port fuel injection of gaseous fuels. Fuel (hydrogen) is supplied at 2 barg. Fuel mass flow is measured using a Bronkhorst

Hi-Tec sensor. 
The test bench was initially equipped with a Zepher turbo compressor (blower), limited to 0.5 barg supercharging pressure. After the first encouraging results (see below), a Busch MM1102BP claw compressor was installed to enable higher supercharging pressures. Both rotors are fitted with a waterproof coating to stand up to the condensation water coming from the EGR-system. A volumetric compressor was chosen in order to be able to supercharge the engine up to 1 barg and higher, at low as well as at high engine speeds. The compressor is driven by a $7 \mathrm{~kW}$ electric motor which is fed by an inverter, allowing varying the inlet pressure by adjusting the compressor speed. Figure 1 shows the layout of the engine system. The theoretical power required for supercharging can be calculated from the measured inlet conditions, the supercharging pressure and the air mass flow [14].

A damper vessel (200 liter) is used to allow intake air mass flow measurements (strongly pulsating flow) with a second Bronkhorst Hi-Tec sensor. The second purpose of this relatively large damper vessel is making the inlet pressure less sensitive to little variations of the compressor speed. On the other hand, a large damper vessel is to the detriment of the time necessary to reach a stable gas composition in case of EGR operation.

In order to control the gas temperature before the gas enters the engine, an adjustable intercooler is placed between the compressor and the damper vessel.

Exhaust gas can be recirculated from the exhaust to the intake of the compressor. The layout as shown in Fig. 1 was chosen to avoid the complexity of a high pressure loop EGR (supercharging + EGR combination). It turned out to be necessary to install a choke valve to create vacuum at the inlet of the compressor. This vacuum overcomes the pressure losses in the relatively long EGR-pipe, and causes a flow of exhaust gases. The surplus of energy to create this vacuum is provided by the compressor.

In order to protect the compressor against excessive inlet temperatures, an EGR-cooler was installed to keep the inlet temperature around $50^{\circ} \mathrm{C}$. This is a compromise because it is necessary to keep the temperature high enough to prevent the production of condensation water in the compressor as much as possible.

At the end of the exhaust system, a TWC was installed. A TWC makes it possible to reduce the NOx emissions at stoichiometric operation. For a more efficient reduction, mixtures slightly rich of stoichiometric should be used so that the small amount of excess hydrogen can act as reducing agent. The recirculation of unburned hydrogen can cause safety problems as the formation of an explosive mixture in the damper vessel is a (albeit unlikely) possibility.

A MoTeC M4Pro engine control unit is used to control ignition timing, start of injection and injection duration. A cold rated spark plug with a silver central electrode was used to minimize spark plug hot spots and catalytic reactions.

\subsection{Emissions}


The exhaust gas components $\mathrm{O}_{2}, \mathrm{CO}, \mathrm{CO}_{2}, \mathrm{NO}, \mathrm{NO}_{\mathrm{x}}$ and $\mathrm{H}_{2}$ are measured. A direct reading of the air to fuel equivalence ratio $\lambda$ is given by a Bosch wide band sensor and a digital air/fuel ratio meter with calibration for hydrogen.

\subsection{Safety}

The engine test bench has a tapered roof with a Buveco Bucom ST600EX hydrogen sensor located at the highest point. As an additional safety measure for the supercharging experiments, a small controlled flow is taken from the damper vessel (less than $0.5 \%$ of the intake flow) through a flow controller and pressure reduction valve to another ST600EX hydrogen sensor. This set-up is necessary as most commercial hydrogen sensors cannot handle strong pressure fluctuations or overpressure. The monitoring of hydrogen concentration in the (large) damper vessel precludes any build-up of a combustible mixture in the supercharged vessel.

In practice, the safety set-up was not working satisfactorily, the time it took for the system to report an excessive hydrogen concentration was too long. The consequences for the experimental procedures are discussed below. The system is currently being revised for a faster response.

\subsection{Determining the EGR percentage}

When running a hydrogen engine with exhaust gas recirculation, it is not possible to use the standard practice of obtaining the amount of recirculated exhaust gases from the $\mathrm{CO}_{2}$ concentration in the intake and exhaust, as only traces of $\mathrm{CO}_{2}$ are present (originating from lubrication oil combustion). Measuring $\mathrm{H}_{2} \mathrm{O}$ concentrations, the main combustion product of hydrogen, as an alternative is not easily done. Nande et al. [15] use the $\mathrm{O}_{2}$ concentrations in intake and exhaust as alternative. However, as EGR is used with stoichiometric mixtures (see below), the oxygen concentration in the exhaust is very low and thus not a good base for accurately determining the EGR rate.

Another method is to start from a lean burn condition, measure the hydrogen and air flow rate, and then opening the EGR valve while keeping the hydrogen mass flow rate constant. The EGR valve is opened until stoichiometry is reached (indicated by the wide band $\lambda$ sensor). The decrease in measured air flow rate is caused by the EGR flow rate, so this can be used to determine the exact magnitude. The EGR percentage, defined as the ratio of mass rate of EGR to the total mass rate (EGR + air + fuel), can then be determined assuming complete combustion, neglecting the $\mathrm{NO}_{\mathrm{X}}$ concentration and measuring the temperature of the recirculated exhaust. An uncertainty analysis resulted in an estimated 5\% relative error for the EGR percentages given in the following.

\section{Results}

\subsection{Atmospheric}

First, some results at atmospheric conditions are discussed to set a baseline for the supercharging experiments. A threshold equivalence ratio, defined as the equivalence ratio where $\mathrm{NO}_{\mathrm{x}}$ emissions reach 100ppm, of $\lambda \sim 2$ was found for this engine. This threshold shifts to slightly richer mixtures at high engine speeds, as the time for $\mathrm{NO}_{\mathrm{X}}$ formation decreases. 
The maximum brake mean effective pressure (bmep) at stoichiometric is only 6.5 bar. However, the volumetric efficiency for this engine is very low, due primarily to the air mass flow meter and extensive piping before and after the damper vessel (see Fig. 1). If the volumetric efficiency is defined as the ratio of the measured air and hydrogen flow to the flow that would fill the swept volume at atmospheric conditions, values of (only) about $70 \%$ are found. Furthermore, friction losses are inherently higher for this single cylinder research engine. Compared to measurements on this engine fueled with methane [16], a 7\% lower bmep is found on hydrogen, which corresponds to what one would expect from the difference in volumetric energy density.

When determining the optimal ignition timing (preferably MBT, minimum spark advance for best torque), it was found that timings to reduce $\mathrm{NO}_{\mathrm{X}}$ emissions also benefit backfire resistance: lowering the peak temperatures also leads to less hot spots in the engine. Late ignition timings also lead to less time for heat transfer to the cylinder walls (evidenced by increased exhaust temperatures). Thus, stoichiometric operation was possible with late (after TDC) ignition. One has to take this into account for (near-) stoichiometric mixtures when doing an IT sweep starting from a large spark advance: when approaching TDC, backfire or pre-ignition can occur due to higher incylinder temperatures, leading one to believe a minimum spark advance is reached. However, jumping to ignition timings after TDC allows backfire-free operation. The high burning velocity of hydrogen explains this behavior, and results in no loss of efficiency even when igniting after TDC [17].

Figure 2 shows the MBT ignition timing as a function of air to fuel equivalence ratio, for different engine speeds, at wide open throttle. The large range in equivalence ratio leads to a large range in burning velocities, with lean, slow burning mixtures requiring more spark advance. The effect of engine speed is most obvious for the lean mixtures, where more spark advance is needed when less time is available (higher engine speed) and burning velocities are relatively low. Near stoichiometric, the burning velocities of hydrogen are so high [18] that there is hardly any influence of the engine speed on MBT timing.

\subsection{Initial supercharging experiments}

Supercharging is a straightforward way to increase the power output of PFI hydrogen engines. However, as incylinder mixture densities are increased the likelihood of hot spot formation also increases. As reported higher, previous experimenting on a Valmet engine showed increased backfire propensity when charging, forcing the use of leaner equivalence ratio. Therefore, the maximum power output could not be increased [8].

Thus, initial experiments on the supercharged single cylinder engine were aimed at determining any power benefit. All measurements reported in this section were with a supercharging pressure of 0.5 barg (measured in the damper vessel). Figure 3 shows the resulting maximum power output as a function of engine speed. The net power output for the supercharging experiments (accounting for the power needed to drive the air blower, calculated from the theoretical supercharging power and an assumed compressor efficiency of $50 \%$ ) is compared to the power output for the atmospheric experiments. The dip at $3000 \mathrm{rpm}$ is due to a drop in volumetric efficiency for this intake configuration. 
Supercharging results in a net power increase of about $40 \%$. This is somewhat less than what could be expected from the supercharging pressure (given that the intercooler is over dimensioned), but is easily explained as stoichiometric operation was no longer possible when supercharging. The air to fuel equivalence ratio $\lambda$ was now limited to 1.3 to 1.4 , because of backfire or pre-ignition. This essentially means that the power increase cannot be used because of the resulting high $\mathrm{NO}_{\mathrm{X}}$ emissions in an oxygen-rich environment. Recycling part of the exhaust gases is a means to displace some of the intake air and enrich the mixture, so experiments with EGR were done to determine the possibility of running stoichiometric at supercharged conditions.

Figure 4 shows the (net) maximum power output as a function of engine speed when exhaust gas recirculation is used while supercharging. Stoichiometric operation is now possible without backfire or pre-ignition events, through increasing both the injected fuel quantity and the EGR rate. The high heat capacity of the recycled exhaust gases (with a high water vapor content) is the reason why the fueling rate can be increased without abnormal combustion phenomena. As a result, not only is stoichiometric operation now possible with efficient $\mathrm{NO}_{\mathrm{X}}$ after treatment, but furthermore the power output can be seen to increase slightly. This results in a net power increase of almost $50 \%$. The maximum brake mean effective pressure now is 9.4 bar. As mentioned higher, this is a research engine with low volumetric efficiency, so this should not be compared to the bmep of a production gasoline engine. Comparing to (atmospheric) measurements on this engine on methane [16], a power increase of about $20 \%$ is found, extrapolating this gives an estimate of the power increase compared to atmospheric gasoline operation of roughly $10 \%$.

\subsection{Extension of the supercharging experiments}

After these initial, encouraging results, another supercharger was installed (see above) so that higher charging pressures could be reached. As explained above, for this engine supercharging at stoichiometric conditions (allowing for after treatment with a TWC) was impossible without EGR. Consequently, in order not to exceed the $\mathrm{NO}_{\mathrm{X}}$ limit of $100 \mathrm{ppm}$, the air-fuel mixture has to be lean enough (lean burn), or EGR has to be used.

First, 'lean burn' experiments were conducted at an engine speed of $2000 \mathrm{rpm}$ and WOT at charging pressures from $0 \mathrm{barg}$ (atmospheric) to $1 \mathrm{barg}$. Measurements were taken with charging pressure steps of $0.2 \mathrm{barg}$. At these measuring points, the richness of the mixture at which the $\mathrm{NO}_{\mathrm{X}}$ emissions remained just below the $\mathrm{NO}_{\mathrm{X}}$ limit of $100 \mathrm{ppm}$ was determined. For every charging pressure, the torque that corresponds with this $\lambda$, is the maximum torque that could be reached, with the $\mathrm{NO}_{\mathrm{X}}$ limit as a restriction. The results of the experiments are shown in Fig. 5. All brake torque and efficiency numbers given in this section are net values, accounting for the energy needed for the supercharging. Concerning the BTE values, the low mechanical efficiency of a single cylinder research engine should be kept in mind, as stated above. However, the main interest is a comparison of BTE values between strategies.

As can be seen in Fig. 5, the minimal richness of the mixture, to keep $\mathrm{NO}_{\mathrm{x}}$ emissions below the threshold, decreases $(\lambda$ increases) as the charging pressure increases. If the air-to-fuel equivalence ratio would not have been increased, the cylinder temperature would increase, accelerating $\mathrm{NO}_{\mathrm{X}}$ formation, resulting in $\mathrm{NO}_{\mathrm{X}}$ emissions higher than $100 \mathrm{ppm}$. Although the mixture richness decreases, brake torque increases with increasing 
charging pressure. A maximum brake torque of $23.9 \mathrm{Nm}$ (bmep $=7.47 \mathrm{bar}$ - if the research engine were to run on gasoline, a maximum bmep of about 8.5 bar is estimated) is reached at the maximum charging pressure (for the current tests) of 1 barg with $\lambda=2.5$.

For atmospheric operation the torque output is $13.3 \mathrm{Nm}$ (bmep $=4.15 \mathrm{bar}$ ) with $\lambda=1.9$. At lean operation, supercharging up to 1 barg thus results in a net torque increase of $80 \%$. Figure 6 shows the backfire limit (air-tofuel equivalence ratio at which backfire occurred) and the corresponding brake torque for charging pressures from 0 to $1 \mathrm{barg}$. This figure shows that the backfire limit is well below the air-to-fuel equivalence ratio at which the $\mathrm{NO}_{\mathrm{X}}$ limit of $100 \mathrm{ppm}$ is reached, so there is no risk of backfire at these points.

As stated above, when combining supercharging with EGR, stoichiometric operation becomes possible. This is due to the diluting effect of the exhaust gases, as a result of which $\mathrm{NO}_{\mathrm{X}}$ formation is reduced. Stoichiometric operation allows for the use of a TWC. However, with this engine configuration, it was not possible to run at exactly $\lambda=1$. Because of the safety reasons discussed above (buffer vessel and low pressure EGR loop, and the safety system reacting too slow), the air-fuel mixture was set slightly lean, with $\lambda \sim 1.07$, so that recirculation of unburned hydrogen is avoided. As with lean operation, measurements were taken at an engine speed of $2000 \mathrm{rpm}$ with charging pressures varying from 0 to $1 \mathrm{barg}$. For this range of charging pressure, the amount of EGR was set so that $\mathrm{NO}_{\mathrm{X}}$ emissions after conversion (i.e. after the TWC) remained just below the $\mathrm{NO}_{\mathrm{X}}$ limit. Thus, with $\mathrm{NO}_{\mathrm{X}}$ emissions as a restriction, the corresponding brake torque is maximal at this EGR percentage for a particular charging pressure. Figure 7 shows the brake torque and EGR percentage as a function of the charging pressure.

In order to keep the cylinder peak temperature and $\mathrm{NO}_{\mathrm{X}}$ formation limited, the EGR percentage increases with increasing charging pressure, with a maximum of $45.9 \%$ at a charging pressure of 1 barg. Similar to the lean operation, the brake torque increases when increasing the charging pressure. At atmospheric operation, the brake torque is $12.3 \mathrm{Nm}$ (bmep $=3.85 \mathrm{bar}$ ), with an EGR rate of about $37 \%$. At 1 barg a maximum torque of $22.6 \mathrm{Nm}$ (bmep $=7.08$ bar) is reached. Supercharging in combination with EGR, results in a power increase over atmospheric operation $(\lambda=1)$ of $84.7 \%$. Figure 8 shows the brake torque (see also Figs. 5 and 6 ) and efficiency for both methods. For the whole pressure range, the efficiency of the lean burn strategy exceeds the efficiency of the $\lambda=1$ (actually 1.07) + EGR operation. This is due to the higher power needed for supercharging of the mixture of EGR and fresh charge at EGR operation, as a result of the higher temperature at the inlet of the compressor. The brake torque that could be achieved is similar for both methods. At $1 \mathrm{barg}$, where the maximum torque for both methods is reached, the torque at lean operation exceeds the torque at EGR operation.

Similar experiments have been conducted at an engine speed of $3000 \mathrm{rpm}$. Table 1 summarizes the results for both engine speeds at a charging pressure of $1 \mathrm{barg}$. As with $2000 \mathrm{rpm}$, the torque and efficiency at $3000 \mathrm{rpm}$ are optimal when operating lean.

When deviating from stoichiometric operation, as done here for safety reasons, the conversion efficiency of the TWC decreases drastically. Therefore, when taking the $100 \mathrm{ppm}$ tailpipe limit into account, the raw $\mathrm{NO}_{\mathrm{X}}$ 
emissions (before conversion) had to be limited. This severely restricts the maximum torque. Taking into account the non-optimized TWC location, low conversion efficiencies were to be expected. When assuming a more realistic (conservative) conversion efficiency of $95 \%$ for the TWC, the restriction on the engine-out $\mathrm{NO}_{\mathrm{X}}$ emissions are less severe (2000 ppm). As a consequence, the necessary EGR percentage decreases to $23 \%$, while brake torque and efficiency increase. At a charging pressure of 1 barg, the brake torque reaches a maximum value of $34.8 \mathrm{Nm}$. This means an increase of $46 \%$ in comparison with the maximum torque at lean operation. This brake torque of $34.8 \mathrm{Nm}$ exceeds the torque of a comparable gasoline engine with almost $30 \%$. The brake thermal efficiency is $27.9 \%$, which is similar to the efficiency at lean burn. These results emphasize the importance of a correct $\lambda$-control.

TWC conversion efficiencies of more than $99 \%$ have been reported for hydrogen-fueled engines [12], so with an optimized engine, even higher power outputs are likely. On the other hand, for these high TWC conversion efficiencies, some unburned hydrogen in the exhaust is needed as a reducing agent, which will adversely affect the brake thermal efficiency.

\section{Conclusion}

The goal of this paper was to study the potential of supercharging to increase the power output of a port fuel injection hydrogen engine, while limiting $\mathrm{NO}_{\mathrm{X}}$ emissions and maximizing efficiency.

A single cylinder research engine was supercharged, increasing the power output substantially compared to the atmospheric case. However, to avoid backfire and pre-ignition, the air to fuel equivalence ratio $\lambda$ was limited to a minimum of 1.3 , which would lead to unacceptable $\mathrm{NO}_{\mathrm{X}}$ emissions. Recycling part of the exhaust gases (EGR) allowed stoichiometric supercharged operation, increasing the maximum power output to gasoline levels and higher, while still enabling efficient after treatment.

When supercharging at equivalence ratios lean of the $\mathrm{NO}_{\mathrm{X}}$ threshold (so that after treatment is not necessary), the maximum power output at the currently used maximum supercharging pressure of 1 barg exceeded that of stoichiometric atmospheric operation but was still lower than what would be obtained on gasoline. Supercharging stoichiometric mixtures, and using exhaust gas recirculation, resulted in power outputs of up to $30 \%$ higher compared to gasoline (assuming a conservative 95\% TWC conversion efficiency), albeit at lower efficiencies compared to the lean burn strategy.

\section{References}

[1]. Verhelst S., Verstraeten S., Sierens R. 'A critical review of experimental research on hydrogen fueled SI engines'. SAE technical paper nr 2006-01-0430, 2006. Also in SAE 2006 Transactions, Journal of Engines, pp264-274, 2007.

[2]. Mohammadi A., Shioji M., Nakai Y., Ishikura W., Tabo E. 'Performance and combustion characteristics of a direct injection SI hydrogen engine’. Int. J. Hydrogen Energy 32:296-304, 2007. 
[3]. Das L.M. 'Hydrogen engines: A view of the past and a look into the future'. Int. J. Hydrogen Energy 15:425-443, 1990.

[4]. Berckmüller M., Rottengruber H., Eder A., Brehm N., Elsässer G., Müller-Alander G., Schwarz C. 'Potentials of a charged SI-hydrogen engine'. SAE technical paper nr 2003-01-3210, 2003.

[5]. Natkin R.J., Tang X., Boyer B., Oltmans B., Denlinger A., Heffel J.W. 'Hydrogen IC engine boosting performance and NOx study’. SAE technical paper nr 2003-01-0631, 2003.

[6]. Lapetz J., Natkin R., Zanardelli V. 'The design, development, validation and delivery of the Ford $\mathrm{H}_{2} \mathrm{ICE}$ E450 shuttle bus'. Proceedings $1^{\text {st }}$ International Symposium on Hydrogen Internal Combustion Engines, Sept. 28-29 2006, Graz, Austria.

[7]. White C.M., Steeper R.R., Lutz A.E. 'The hydrogen-fueled internal combustion engine: a technical review'. Int. J. Hydrogen Energy 31:1292-1305, 2006.

[8]. Sierens R., Rosseel E. 'The computation of the apparent heat release for a hydrogen fueled engine'. Proceedings ASME Fall Technical Conference, ICE 27-3:99-108, 1996.

[9]. Verhelst S. 'A study of the combustion in hydrogen-fueled internal combustion engines'. PhD thesis, Ghent University, Gent, Belgium, 2005, http://hdl.handle.net/1854/3378.

[10]. Wallner T., Lohse-Busch H., Gurski S., Duoba M., Thiel W., Martin D., Korn T. 'Fuel economy and emissions evaluation of BMW Hydrogen 7 Mono-Fuel demonstration vehicles'. Int. J. Hydrogen Energy 33:7607-7618, 2008.

[11]. Verhelst S., Sierens R. 'Hydrogen engine-specific properties’. Int. J. Hydrogen Energy 26:987-990, 2001.

[12]. Rottengruber H., Berckmüller M., Elsässer G., Brehm N., Schwarz C. 'A high-efficient combustion concept for direct injection hydrogen internal combustion engine'. 15th World Hydrogen Energy Conference, paper nr 28J-01, Yokohama, Japan, 2004.

[13]. Heffel J.W. 'NOx emission and performance data for a hydrogen fueled internal combustion engine at 1500 rpm using exhaust gas recirculation’. Int. J. Hydrogen Energy 28:901-908, 2003.

[14]. Heywood J.B. 'Internal Combustion Engine Fundamentals'. McGraw-Hill, Inc. ISBN 0-07-028637-X, 1988.

[15]. Nande A. M., Szwaja S., Naber J. D. 'Impact of EGR on Combustion Processes in a Hydrogen Fueled SI Engine'. SAE paper nr. 2008-01-1039, 2008.

[16]. Verstraeten S., Sierens R., Verhelst S. 'A high speed single cylinder hydrogen fueled internal combustion engine'. Proceedings Fisita World Automotive Student Congress, Barcelona, 2004.

[17]. Verhelst S., Sierens R. 'Combustion studies for PFI hydrogen IC engines'. SAE technical paper nr $2007-$ 01-3610, 2007.

[18]. Verhelst S, Woolley R, Lawes M, Sierens R. 'Laminar and unstable burning velocities and Markstein lengths of hydrogen-air mixtures at engine-like conditions'. Proceedings of the Combustion Institute 30:209-16, 2005. 


\section{Figure and table captions}

\section{Figure captions}

Figure 1. Single cylinder engine bench layout.

Figure 2. MBT ignition timing as a function of air to fuel equivalence ratio, for different engine speeds, WOT. Figure 3. Brake power as a function of engine speed. WOT, atmospheric operation at stoichiometric; and supercharged operation at backfire/pre-ignition limited equivalence ratio $(\lambda=1.3-1.4)$.

Figure 4. Brake power as a function of engine speed. WOT, atmospheric operation at stoichiometric; supercharged operation at backfire/pre-ignition limited equivalence ratio $(\lambda=1.3-1.4)$; and supercharged operation with EGR at stoichiometric $(\lambda=1)$.

Figure 5: Supercharging at the $\mathrm{NO}_{\mathrm{x}}$ threshold, using the WOT lean burn strategy: brake torque and air-to-fuel equivalence ratio as a function of the charging pressure, $2000 \mathrm{rpm}$.

Figure 6: Backfire limit as a function of supercharging pressure, $2000 \mathrm{rpm}$.

Figure 7: Supercharging at the $\mathrm{NO}_{\mathrm{X}}$ threshold, using the stoichiometric + EGR strategy: brake torque and EGR percentage as a function of the charging pressure $(\lambda=1), 2000 \mathrm{rpm}$.

Figure 8: Comparison of brake torque and efficiency as a function of supercharging, between lean burn operation and stoichiometric+EGR operation, at the $\mathrm{NO}_{\mathrm{X}}$ threshold, $2000 \mathrm{rpm}$.

\section{Table captions}

Table 1: Comparison of maximum brake torque and corresponding efficiency when supercharging, between lean burn operation and stoichiometric+EGR operation, at the $\mathrm{NO}_{\mathrm{X}}$ threshold, for $2000 \mathrm{rpm}$ and $3000 \mathrm{rpm}$. 


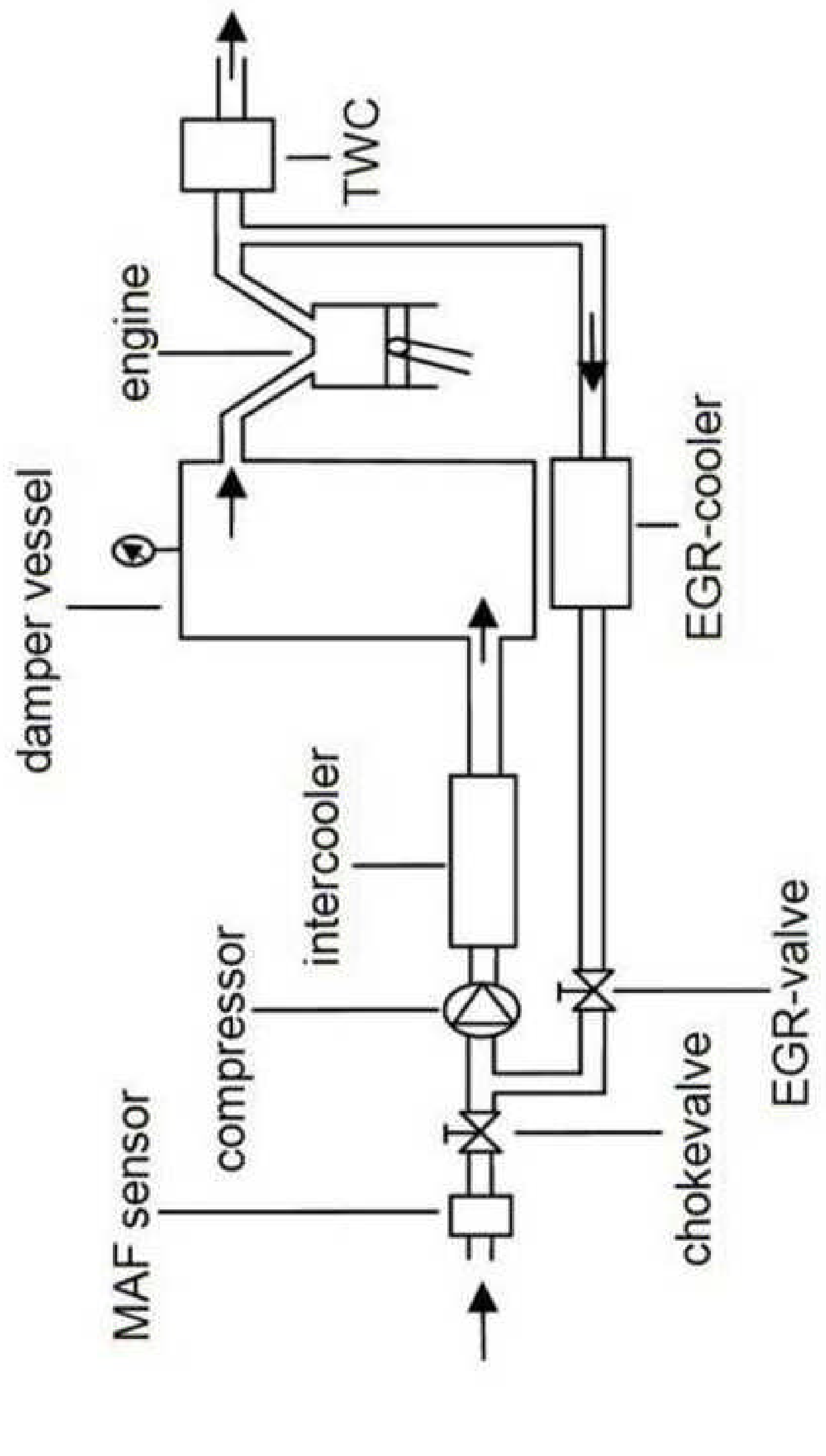




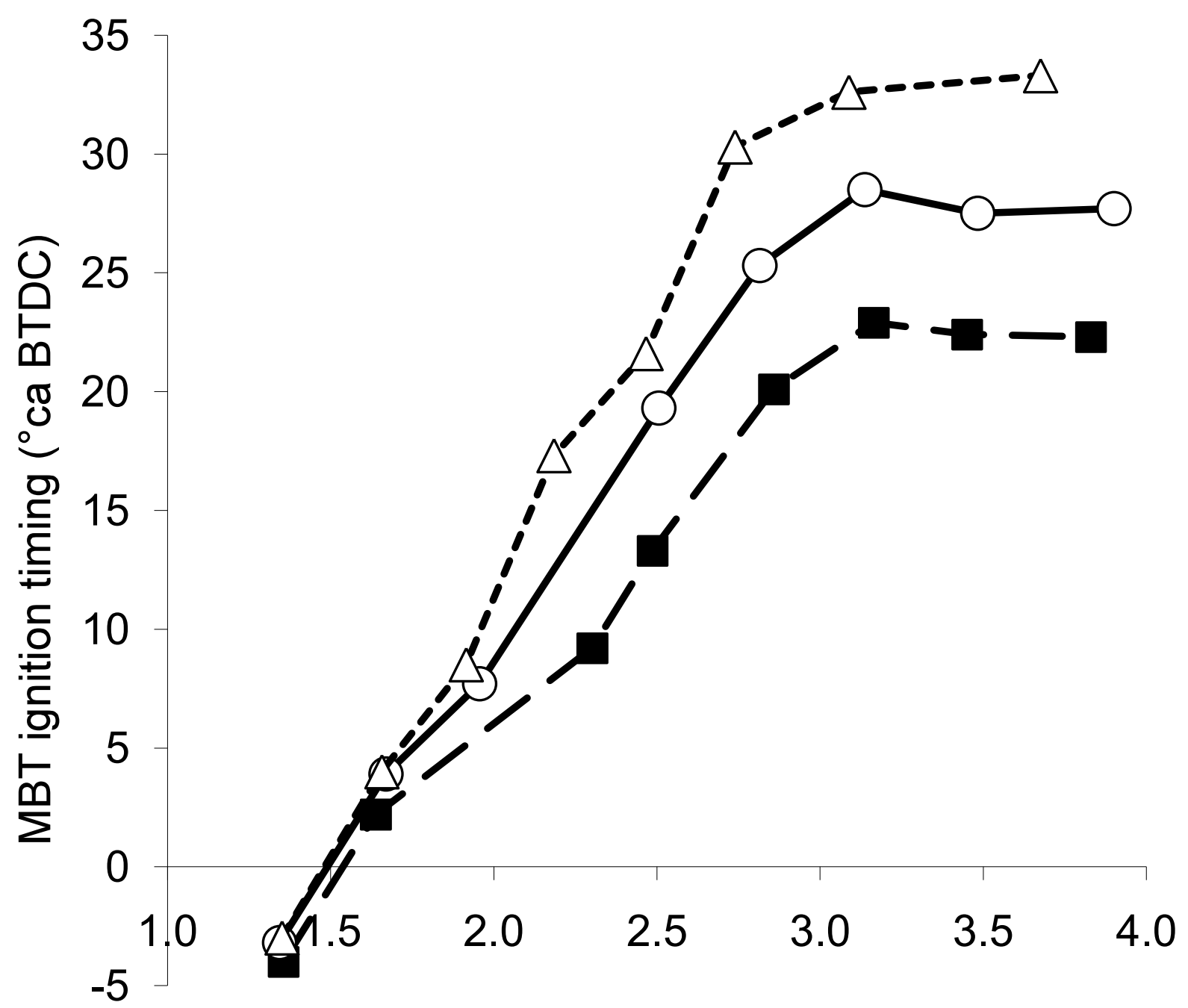

air to fuel equivalence ratio (-)

$\rightarrow-2000 \mathrm{rpm} \quad-0-3000 \mathrm{rpm} \quad-\rightarrow-4000 \mathrm{rpm}$ 


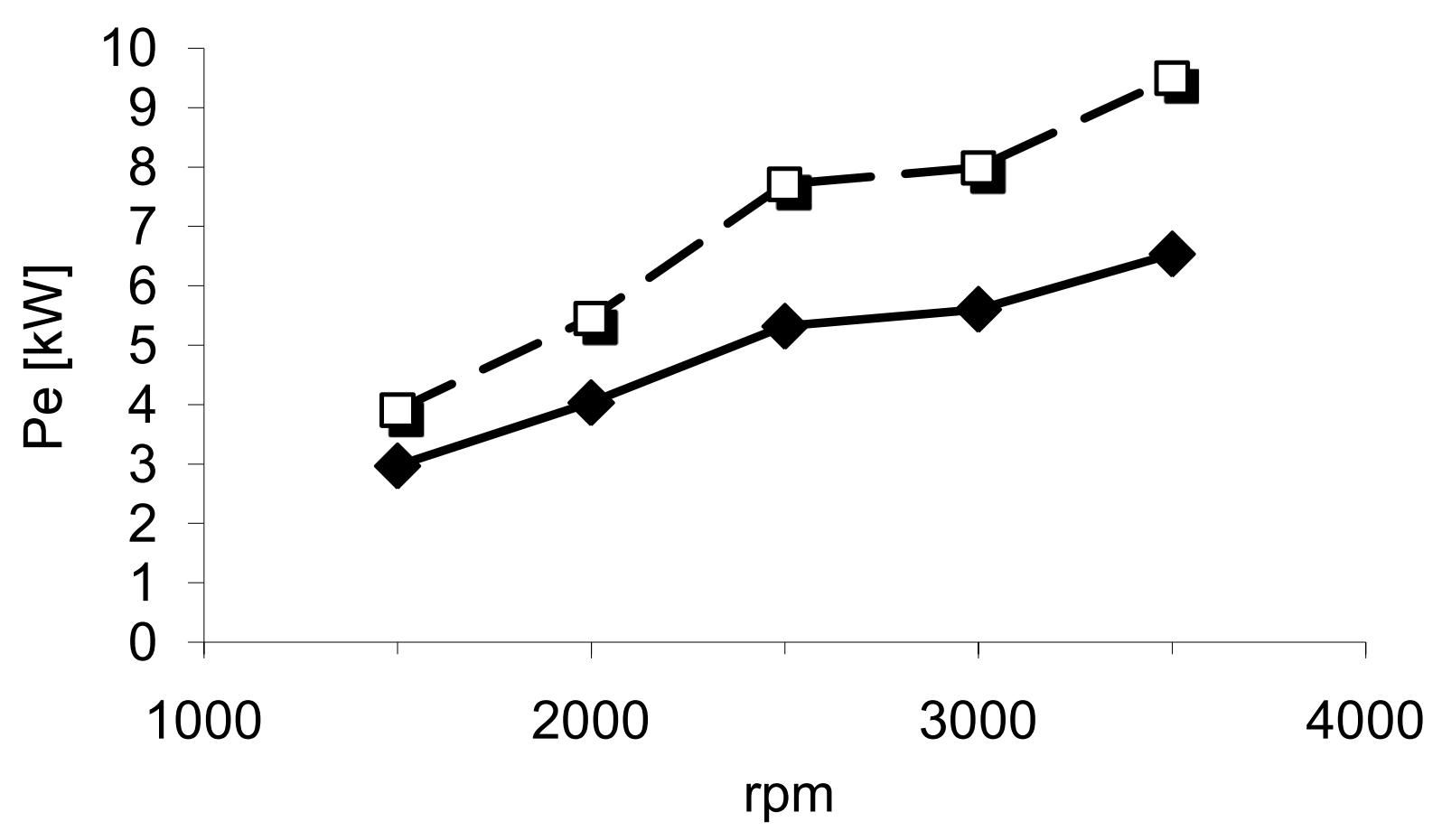

$\multimap$ Atmospheric $\longrightarrow$-Supercharged 0.5 barg 


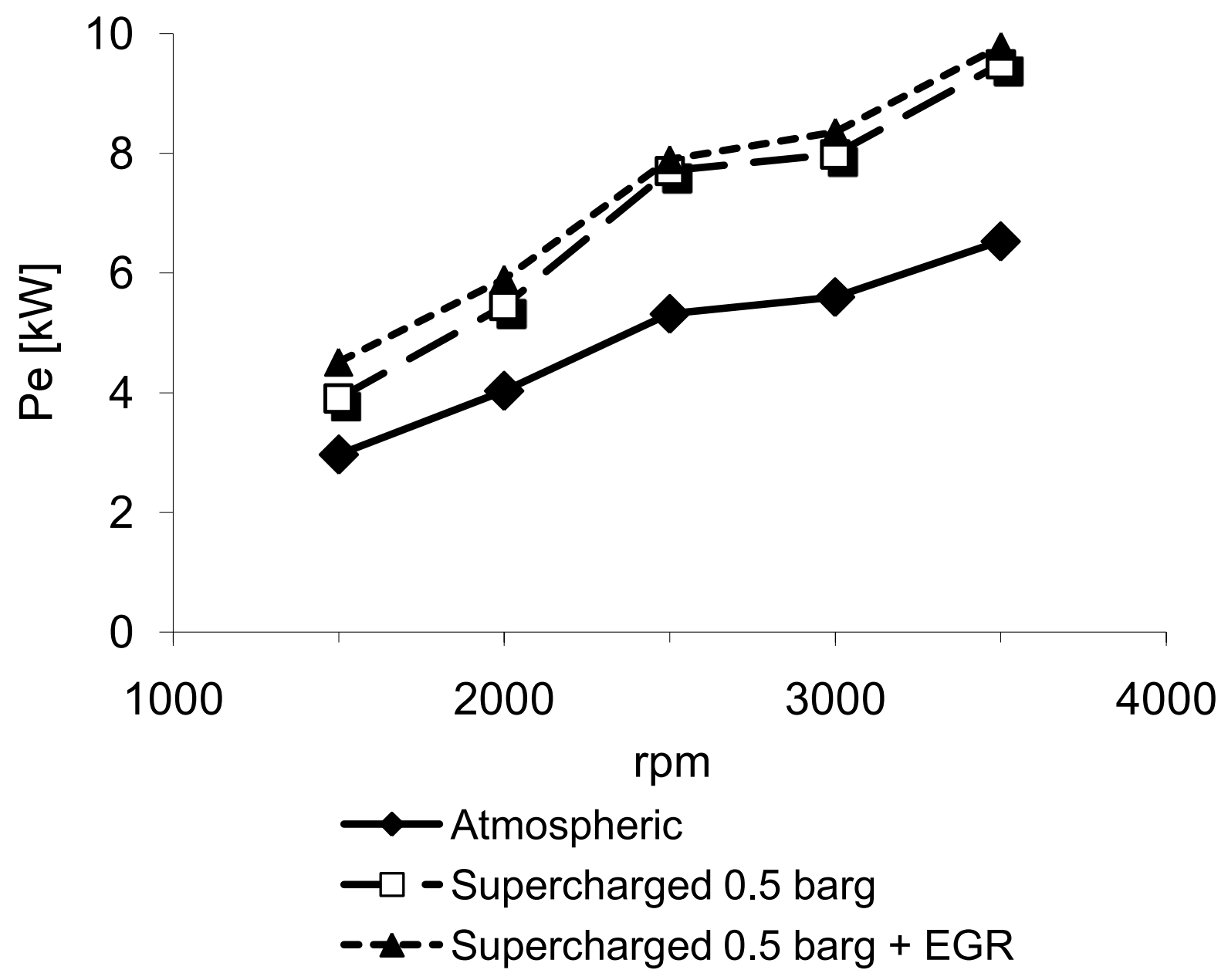


$(-) x$
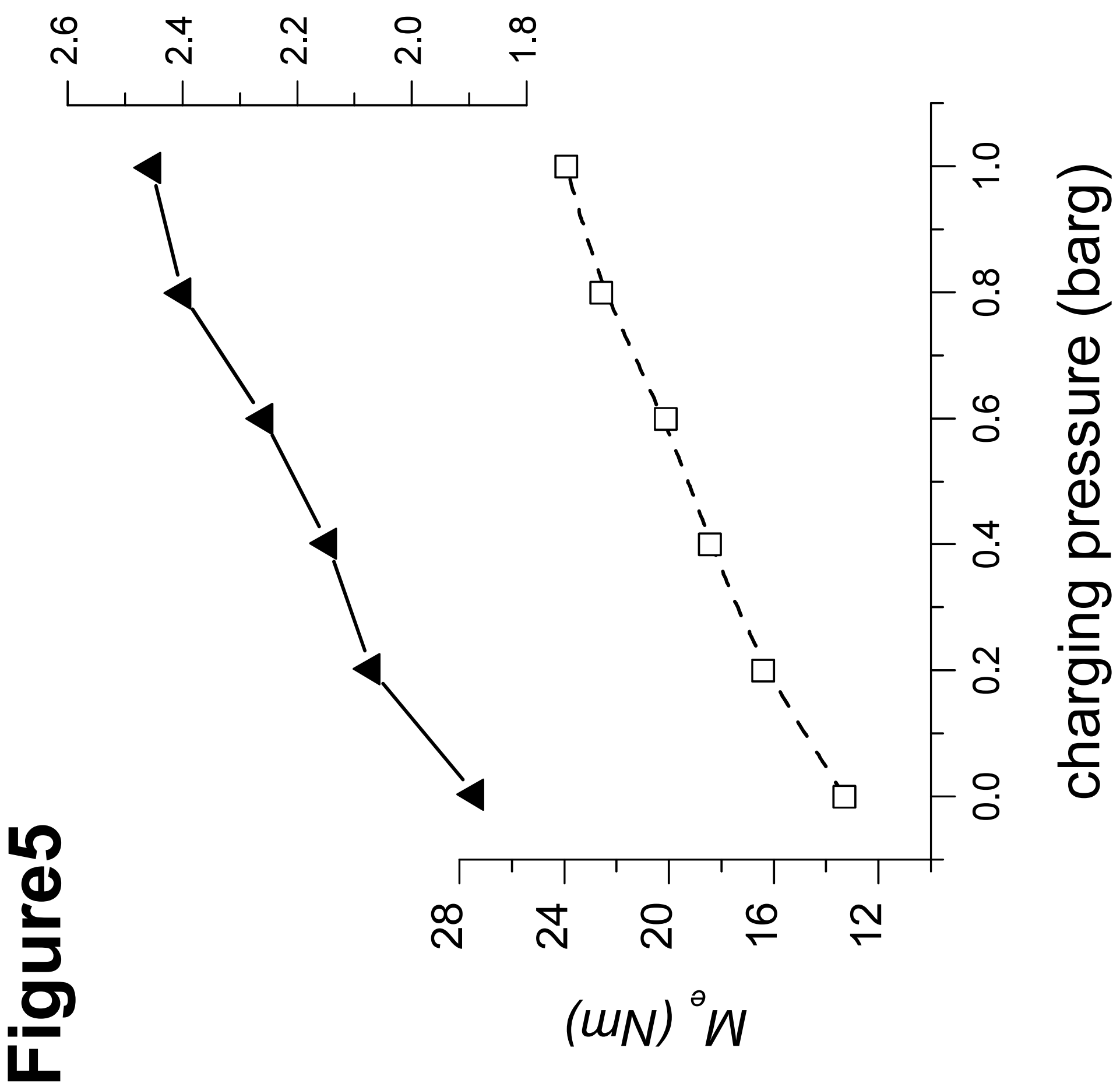


\section{(uN) ənbıо әуедg}

요ํ $\stackrel{m}{\sim} \stackrel{\sim}{\sim}$

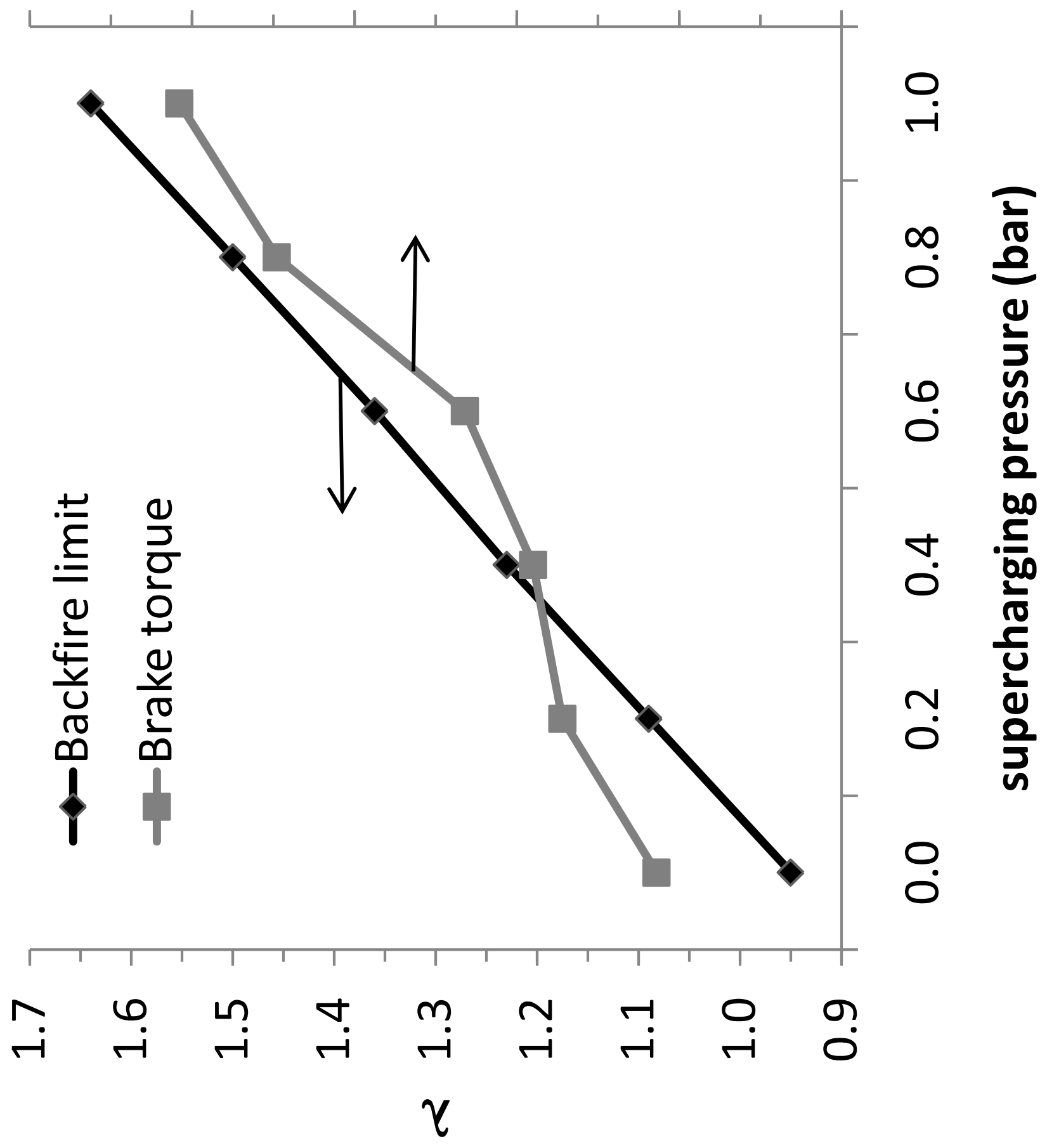


$E G R \%$

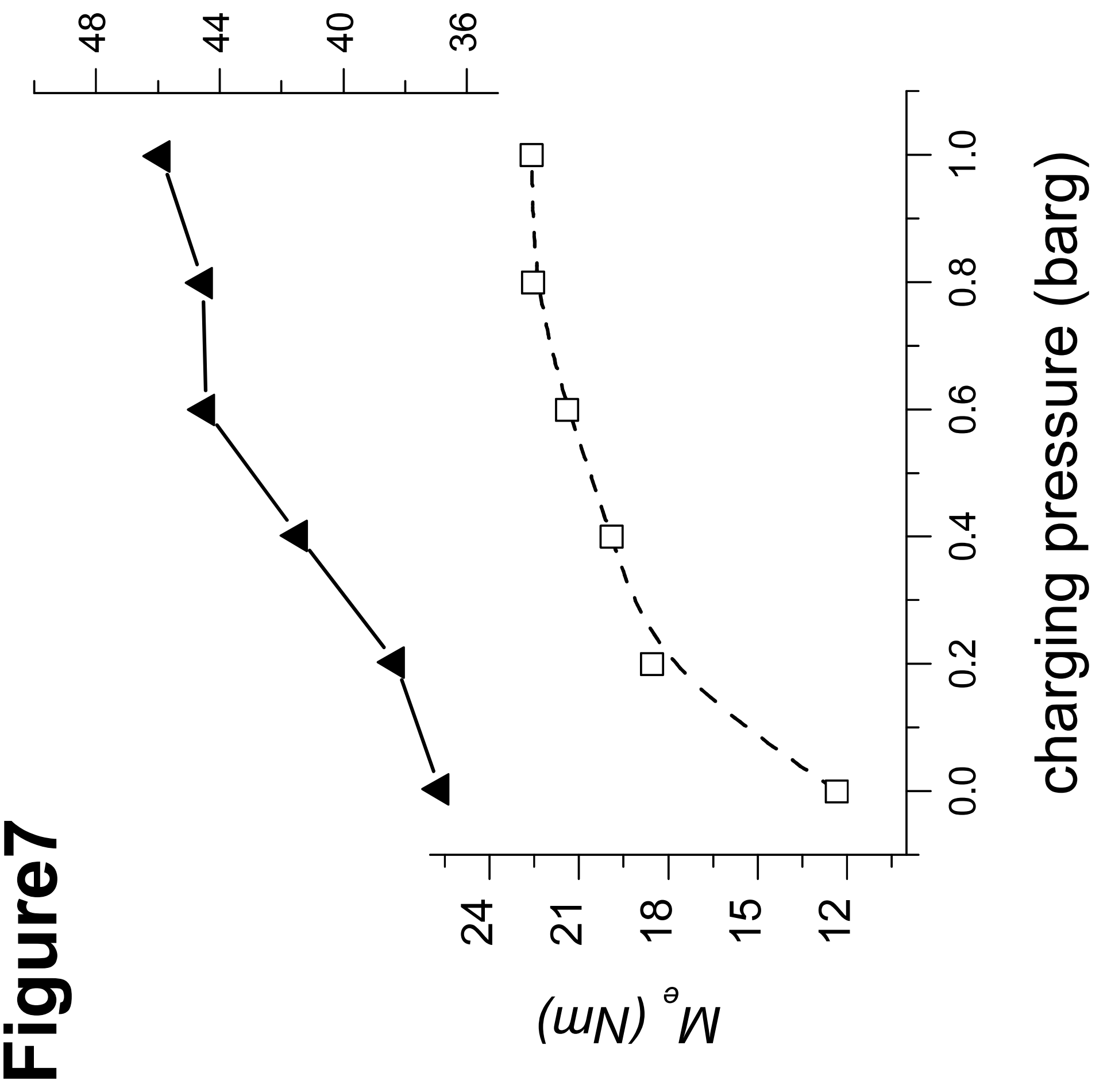


BTE (\%)

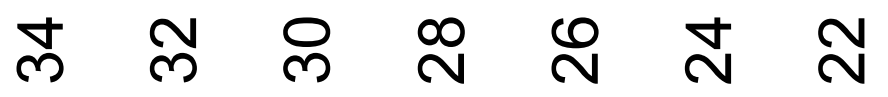

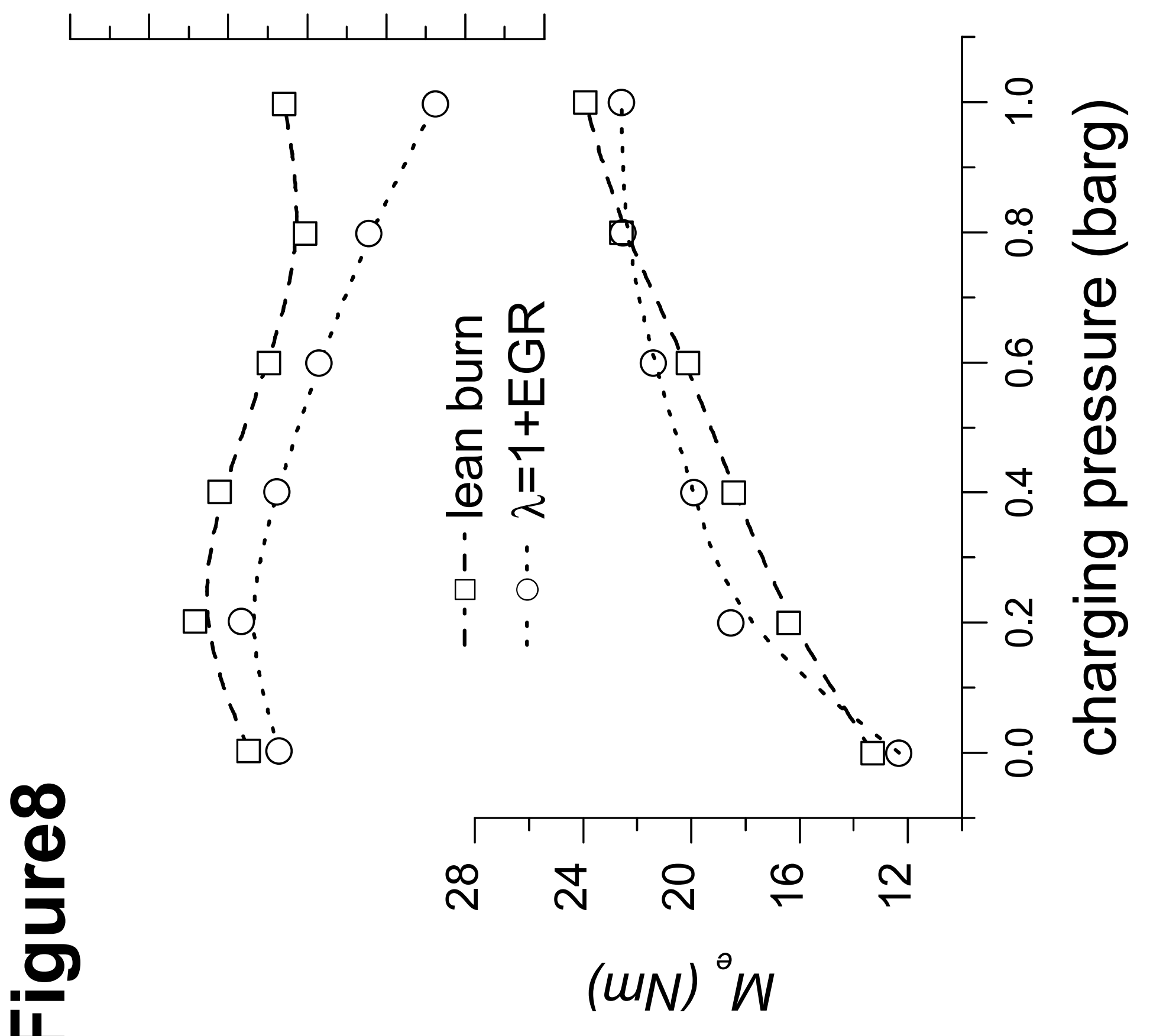




\begin{tabular}{l|cc|cc} 
& \multicolumn{2}{|c|}{ Lean burn } & \multicolumn{2}{c}{$\lambda=1+$ EGR } \\
Engine speed & $\mathrm{M}_{\mathrm{e}}(\mathrm{Nm})$ & $\mathrm{BTE}(\%)$ & $\mathrm{M}_{\mathrm{e}}(\mathrm{Nm})$ & $\mathrm{BTE}(\%)$ \\
\hline $2000 \mathrm{rpm}$ & 23,9 & 28,6 & 22,6 & 24,7 \\
$3000 \mathrm{rpm}$ & 25,6 & 27,7 & 21,6 & 22,5
\end{tabular}

Table 1: Comparison of maximum brake torque and corresponding efficiency when supercharging, between lean burn operation and stoichiometric+EGR operation, at the $\mathrm{NO}_{\mathrm{X}}$ threshold, for 2000 rpm and $3000 \mathrm{rpm}$ 